\title{
8. UPLIFT AND EXPOSURE HISTORY OF THE CÔTE D'IVOIRE-GHANA TRANSFORM MARGIN: GEOCHEMISTRY OF PORE-FILLING AND FRACTURE VEIN CALCITES ${ }^{1}$
}

\author{
Maria C. Marcano, ${ }^{2}$ Kyger C. Lohmann, ${ }^{2}$ and Elizabeth A. Pickett ${ }^{3}$
}

\begin{abstract}
Reefal and peri-platform carbonates of late Albian to Turonian-Cenomanian age were recovered from Leg 159 Ocean Drilling Program (ODP) Sites 959, 960, and 962 which were drilled on the Côte D'Ivoire-Ghana Transform Margin. These deposits thicken and coarsen from the Deep Ivorian Basin southward toward the marginal ridge and are intercalated with pelagic micrites containing abundant planktonic foraminifers. The stratigraphic relations along with the nature of the skeletal grains and intraclasts in the carbonates suggest a depositional setting of a shallow carbonate platform that rimmed an emergent metamorphic and sedimentary terrane that served as a coeval source of clastic and carbonate components.

Carbonate-rich horizons are characterized by dissolution of aragonitic bioclasts, recrystallization of micrite to microspar, and infilling of primary and secondary porosity by equant to prismatic low-Mg calcite cements. Preservation of grain morphologies as uncompacted micrite rinds suggests early dissolution and concomitant cementation at the sediment-surface or during shallow burial. Late-stage fracturing of these units during syn- and post-transform deformation is marked by extensive mineralization by quartz, barite, clay, and calcite vein fills.

Based on paragenetic relations and isotopic composition, multiple stages of fracturing and mineralization are identified. All cements and fracture vein calcites have $\delta^{13} \mathrm{C}$ values significantly more negative than primary marine compositions, suggesting a dominant role of organic matter decomposition in controlling the isotopic composition of diagenetic fluids. The oxygen isotopic composition of cements and vein fills range from $-1 \%$ to $-10 \% \delta^{18} \mathrm{O}$. Of these, the first stage is interpreted as forming during progressive subsidence under increasing temperature conditions. A late fracturing event is recorded by calcite whose composition ranges from $-8 \%$ o to $-10 \%$. Assuming a reasonable range of interstitial water compositions, $-5 \%$ o to $+2 \%$ o standard mean ocean water (SMOW), a maximum emplacement temperature of less than $90^{\circ} \mathrm{C}$ is estimated for late fracture vein calcites. This stage of fracturing and calcite mineralization, which reflects the highest temperature event of calcite formation, occurs in units as young as early Eocene in age and requires precipitational temperatures in excess of those expected from typical burial diagenesis. In light of the high temperature of emplacement, this last stage of deformation is interpreted as forming during the passing of the spreading ridge along the Côte D'Ivoire-Ghana Transform Margin during early Eocene time, a time much later than predicted based upon previous studies.
\end{abstract}

\section{INTRODUCTION}

The general progression of structural deformation and uplift has been reconstructed from the evolution of sedimentary environments interpreted from cores recovered along the Côte D'Ivoire-Ghana Marginal Ridge (Fig. 1) as part of Leg 159 shipboard observations (Mascle et al., 1996). A primary objective of this research was to test the tectonic and environmental evolution model of Basile et al. (1992, 1993) and Mascle et al. (1995), which was based on observations from seismic and submersible surveys. Overall, they proposed a sequence of tectonic stages for this transform margin representing the progression from (1) Continent-Continent, Syn-transform Stage (strike-slip, extensional, and compressional deformation); (2) Continent-Ocean Transform or Marginal Ridge Emergence Stage (reflected by structural relaxation and/or thermal uplift of the margin); and (3) Passive Margin Stage (indicated by deepening of the marginal ridge and regional subsidence). It is important to note that the timing and nature of deformation and uplift, which may have occurred as the spreading ridge passed by the Côte D'Ivoire-Ghana Transform Margin, remains poorly constrained (Mascle et al., 1993, 1994, 1995; Basile, 1990; Basile et al., 1992, 1993). Two alternative, viable scenarios prevail (Shipboard Scientific Party, 1996a): (1) passage of the spreading ridge during the latest Albian through Coniacian times, or (2) passage as late as the late Paleocene through early Eocene times.

${ }^{1}$ Mascle, J., Lohmann, G.P., and Moullade, M. (Eds.), 1998. Proc. ODP, Sci. Results, 159: College Station, TX (Ocean Drilling Program).

${ }^{2}$ Department of Geological Sciences, The University of Michigan, Ann Arbor, MI 48109-1063,U.S.A. Correspondence author: kacey@umich.edu

${ }^{3}$ Department of Geology and Geophysics, Grant Institute, West Mains Road, Edinburgh EH9 3JW, United Kingdom.
Therefore, a principal objective of this research was to decipher this history by evaluating the emplacement temperatures and settings of secondary minerals present within intergranular porosity of reefal limestones and tectonic fracture veins, and by placing these within the context of the evolution of depositional and diagenetic environments.

Two principal features that can provide insight into the uplift and deformation history are present within the succession of late Albian to Recent sediments recovered as part of Leg 159. These include mineralized tectonic fracture veins that are distributed throughout the Albian-aged strata and extend locally upward into late Paleocene and early Eocene strata. In addition, abundant bioclastic limestones developed in Late Albian- to Coniacian-aged strata reflect colonization of an emergent ridge adjacent to the transform margin, the Côte D'Ivoire-Ghana Marginal Ridge. Because of the abundance of secondary mineral phases within this stratigraphic succession, it is possible to utilize their chemistries and petrogeneses to reconstruct the temporal evolution of fluid composition and temperatures that changed in concert with the tectonic transitions outlined above.

Within the constructional framework of carbonate vein and porefilling cements, a sequential record of diagenetic conditions can be retrieved by sampling different paragenetic stages of these carbonates. In calcite, these growth stages can frequently be identified petrographically through the use of cathodoluminescence microscopy, or, in the case of tectonic veins, through an analysis of crosscutting relationships. Given a framework of relative timing, it is possible to then reconstruct the compositional evolution of these secondary mineral phases and infer primary changes in the temperatures of diagenesis.

Carbon and oxygen isotopic analysis has been undertaken to constrain the temporal changes in composition that have occurred 
Figure 1. Location map of sites on the Côte D'IvoireGhana Transform Margin drilled as part of ODP Leg 159.

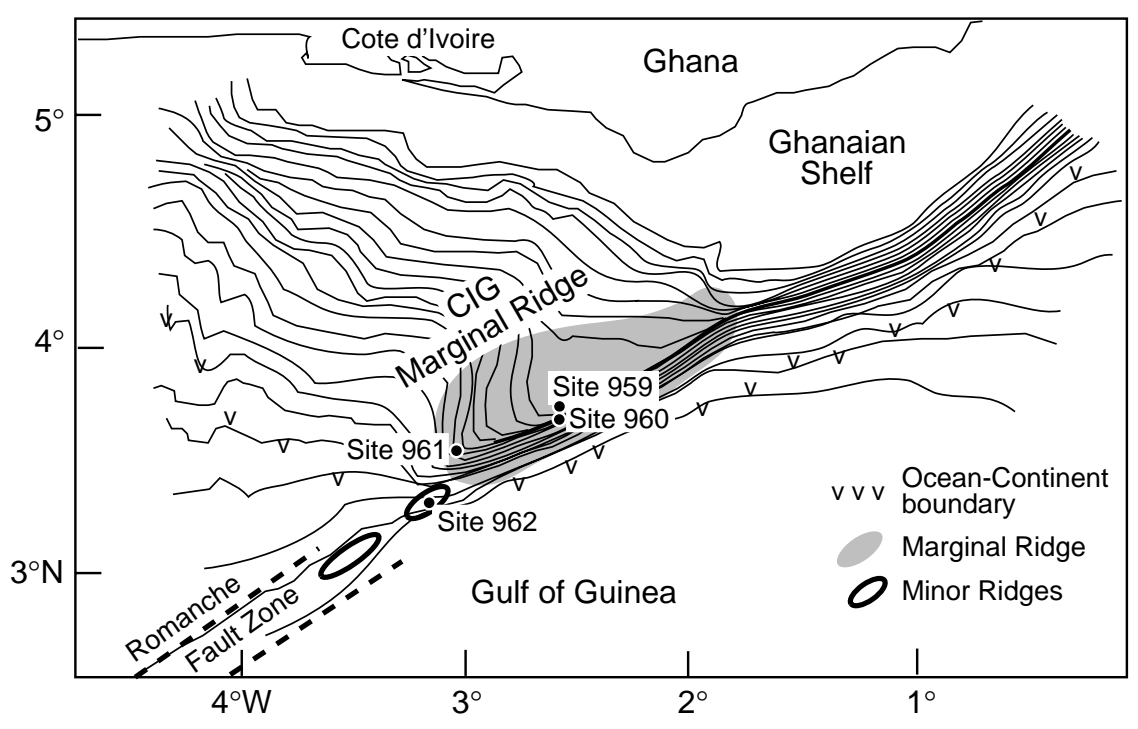

METHODS

throughout the sequence. Oxygen isotopic analysis provides an independent estimate of relative temperature (given some assumption of the fluid compositions), whereas evaluation of combined variation in carbon and oxygen isotopic composition is useful for discerning temporally distinct events of carbonate precipitation. For example, although oxygen isotopic composition is controlled by the composition and temperature of the fluid, the carbon isotope composition reflects varying contributions of carbonate from organic vs. rock sources. As such, it is typical to observe a high degree of variation in carbon isotope values while oxygen isotopic composition remains relatively invariant for any given stage of cementation. If the hypothesis of elevated thermal effects being a result of the passage of the spreading ridge is correct, this event may be discernible by more negative $\delta^{18} \mathrm{O}$ values associated with convection of warmer fluids through the overlying sedimentary succession.

Although a major emphasis of this research has been to document late stage diagenetic effects, additional research has concentrated on early stages of cementation in peri-platform limestones that formed on the Côte D'Ivoire-Ghana Marginal Ridge. At Sites 959 and 960, these limestones were deposited directly above deformed lacustrine to transitional marine sediments of the late Albian age, and therefore must reflect deposition by the periodic transport from shallow-water environments developed along the axis of the marginal ridge. This is evidenced in part by the intercalation of pelagic, planktonic foraminifer-rich sediments and strata of reefal debris, which, in turn, contain abundant coarse-grained siliciclastic quartz and siltstone cobbles. Texturally, these limestones are grainstones to packstones that have undergone extensive secondary dissolution. Dissolution of metastable phases, aragonitic allochems, and bioclasts, and preservation of original grain boundaries by well-preserved uncompacted micritic rinds suggest active dissolution prior to extensive burial. It is important to note that this porosity has been infilled by sparry calcite. This argues for an early mode of formation of intergranular pore-filling carbonate cements, perhaps related to an episode of active uplift of shallow-water carbonate platforms after formation of the ridge, but prior to the onset of passive subsidence. Without further study, it is not possible to determine whether this uplift occurred in response to structural relaxation of the margin coincident with the end of continent-continent transform tectonics or may record a later thermally induced uplift related to the passage of the spreading ridge. Thus, it is critical to evaluate the uplift and exposure history of these carbonate sequences to determine whether (1) the limestones formed during the initial submergence of the marginal ridge as it began to passively subside, or (2) they reflect peri-platform debris aprons formed as a consequence of multiple episodes of uplift and erosion of reefs colonizing the axis of the marginal ridge.
Samples utilized in this study include both thin sections and polished slabs of lithified sediments that possess either mineralized veins or abundant carbonate allochems. These samples are primarily from Unit IV from Sites 959 and 960; however, additional samples were examined from younger stratigraphic units where mineralized veins were present. All samples were examined with standard reflected and transmitted light microscopy techniques to determine the nature of grain constituents, diagenetic cements, and vein mineralization phases. Thin sections were additionally examined under cathodoluminescence microscopy to aid in the identification and discrimination of successive phases of carbonate cements. This method, however, proved relatively fruitless given the low degree of luminescence possessed by cements present in these samples.

Based on the petrographic framework developed through microscopic study, microsamples of vein carbonate and intergranular cements were taken from polished slab surfaces utilizing a $300-\mu \mathrm{m}-$ diameter drilling burr. This method yielded approximately 200 to 400 $\mu \mathrm{g}$ of carbonate powder and allowed individual carbonate components to be sampled for isotopic analysis. Because of the thicker occurrence of vein carbonates, when compared to inter-granular cements, veins provided a better record of end-member phases whereas samples of cements may reflect some degree of mixing among successive stages of cementation.

Prior to analysis, all carbonate powdered samples were roasted in vacuo at $380^{\circ} \mathrm{C}$ for $1 \mathrm{hr}$ to remove volatile contaminants and then reacted at $73^{\circ} \mathrm{C}$ with anhydrous phosphoric acid in individual reaction vessels attached to an automated extraction and analysis system (a Kiel device coupled to a Finnigan-MAT 251). Oxygen isotope enrichments were corrected for ${ }^{17} \mathrm{O}$ contributions and are reported in per mil $(\%)$ relative to the Peedee belemnite (PDB) standard. Precision was maintained at better than $0.1 \%$ o for both $\delta^{13} \mathrm{C}$ and $\delta^{18} \mathrm{O}$, and was monitored by daily analysis of the National Bureau of Standards (NBS) powdered standards.

\section{EVOLUTION OF THE DEPOSITIONAL SETTING}

The evolution of the depositional environments of the Côte D'Ivoire-Ghana Transform Margin provides constraints on the sequence and style of tectonic events that accompanied the breakup and subsequent rifting of the South American and African continents. Interpretation of the depositional history is based largely on shipboard observations. This history is summarized below. 
Deposition in the region of the Côte D'Ivoire-Ghana Transform Margin is first recorded in lacustrine to marginal marine sediments of Unit V at Sites 959, 960, and 961. This succession reflects the formation of transpressional and transtensional basins during the continentcontinent syn-transform stage (Mascle et al., 1993). Finely laminated siltstones and sandstones rich in siderite concretions and cements grade upward into pyritic, fine sandstone and siltstone lithologies. The evolution of the depositional environments of this sequence provides insight into the initial stages of rifting of the South American and African continents during the Early Cretaceous. Continental depositional environments evolved into marine settings as continued rifting permitted progressive encroachment of marine waters into transform-related tectonic basins.

Uplift and deformation of syn-transform sediments are marked by the development of an erosional and angular unconformity at Sites 959 and 960, with a change in the depositional setting from lacustrine and marginal marine to normal marine conditions. The extent of the hiatus is unknown between uplift and the resumption of marine deposition. However, initiation of reefal carbonates on the marginal ridge during the late Albian is indicated by peri-platform deposits of reefal debris that were transported into deeper parts of the basin and intercalated with pelagic sediments composed of abundant planktonic foraminifers (Sites 959 and 960).

Limestones at both Sites 959 and 960 (Unit IV) comprise an intermixture of carbonate allochems (skeletal grains, pellets, ooids, and intraclasts) and resedimented clastic debris. This terrigenous debris includes clasts of lightly lithified silt and sandstones, rounded to angular clasts of metamorphic and igneous quartz and quartzite, and angular plagioclase feldspars. While the majority of siliciclastic intraclasts may reflect the reactivation of previously deposited sediments, the abundance of angular quartz and feldspar requires a sediment source that derives from primary igneous and metamorphic terranes. In addition, the abundance and grain size of the clastic sediments increase progressively from Site 959 southward toward Site 960. This argues for a southerly source, likely reflecting exposure of continental crust along the axis of the marginal ridge during the late Albian through Coniacian times (Shipboard Scientific Party, 1996c).

Cessation of limestone deposition is marked by the development of regionally extensive hardgrounds comprising phosphatic and manganese nodules and glauconitic sands (lower Unit III at Site 959; Unit IVA at Site 960) and records a deepening of the marginal ridge. The termination of clastic input, which led to hardground development, may reflect the detachment of continental sources with the westward drift of South American crustal blocks and slivers and/or substantial deepening across the crest of the ridge. At Site 960, sediments reflect oxidizing conditions and, based on benthic foraminifer ecological constraints, depositional depths are estimated to be $>200 \mathrm{~m}$ (R.D. Norris, pers. comm., 1995). Significantly, to the north at Site 959 during this time period, $>200 \mathrm{~m}$ of black, organic-rich claystones were deposited within the intra-shelf Deep Ivorian Basin (Unit III, Site 959) under dysaerobic conditions. Such regional relations argue for the existence of a topographically elevated marginal ridge during this time which isolated the Deep Ivorian Basin from open circulation of oxygenated marine waters and minimized sediment accumulation on the ridge axis.

The nature of the marginal ridge changed dramatically during the late Paleocene and early Eocene. While black claystones grade upward into nannofossil chalks and biosiliceous sediments at Site 959D, palygorskite-rich claystones replete with barite concretions were being formed on the marginal ridge at Sites 960 and 961 (and possibly 962). Although the precise mechanism for development of the palygorskite claystones and for precipitation of authigenic barite is not yet resolved, their occurrence at these sites further emphasizes the structural and depositional differences which existed between the Deep Ivorian Basin at Site 959 and the marginal ridge at Sites 960 and 961.

Throughout the region, sedimentation from the middle Eocene time is best characterized as the Passive Margin stage (Shipboard Sci- entific Party, 1996a) with deposition of biosiliceous, pelagic, and hemipelagic sediments throughout the region. Though differences exist among sites with respect to carbonate preservation and sediment accumulation, the general pattern of deeper water deposition on a gradually subsiding continental margin best describes the environmental setting from the middle Eocene through the Holocene.

\section{ISOTOPIC COMPOSITION OF FRACTURE VEIN AND INTERGRANULAR CALCITE CEMENTS: RESULTS AND INTERPRETATIONS}

Carbon and oxygen isotope data were collected for calcite occurring in tectonic fracture veins and as cements in the intergranular porosity of limestone lithologies. Fractures mineralized by calcite, clays, and quartz occur over a broad stratigraphic range, from the oldest Albian-aged units recovered to the early Eocene sequence. These veins are typically multiphase, reflecting the sequential precipitation of chalcedony, clays (nacrite; M. Holmes, pers. comm., 1996), and calcite. Multiple events of veining are locally present and are recorded by cross-cutting relationships. Intergranular cements comprise equant to bladed calcites that infill primary and secondary (dissolution) porosity within the limestone-dominated lithologies. In general, sampling of intergranular cements was more difficult than sampling of vein-filling calcites because of their small physical size; thus, the cement data likely reflect intermixtures among numerous stages of calcite emplacement. By contrast, because fracture veins are typically much wider and the calcite fill was more easily sampled, analyses of fracture vein calcites more clearly define separate events of diagenesis and calcite cementation.

When all $\delta^{18} \mathrm{O}$ and $\delta^{13} \mathrm{C}$ values and carbonate phases are examined (Fig. 2), they differ dramatically from the expected range of primary compositions for marine components. Two distinct populations, however, are distinguishable: (1) a broad population characterized by highly variable $\delta^{13} \mathrm{C}$ values (-22\%o to $-1 \%$ ) and a range in $\delta^{18} \mathrm{O}$ from $0 \%$ to $-5 \%$, and (2) a comparatively invariant population with $\delta^{13} \mathrm{C}$ values of $-5 \%$ o to $-7 \%$ and $\delta^{18} \mathrm{O}$ values of $-8 \%$ o to $-10 \%$. Typically, isotopic compositions of carbonate allochems and cements that have formed under shallow-water conditions fall within the range of $+4 \%$ o to $0 \%$ o $\delta^{13} \mathrm{C}$ and $-1 \%$ o to $-3 \%$ o $\delta^{18} \mathrm{O}$ (James and Choquette, 1990). Similarly, diagenetic alteration under deeper (and colder) water conditions would manifest in more positive $\delta^{18} \mathrm{O}$ values ranging from 0\%o to $+4 \%$ o (James and Choquette, 1990; Freeman-Lynde et al., 1986). Evidence of such low-temperature seafloor diagenesis is not observed in the composition of components measured from these sites. Rather, cementation and alteration of allochems must have occurred under conditions where $\delta^{18} \mathrm{O}$ and $\delta^{13} \mathrm{C}$ values are controlled by elevated temperatures and organic reactions occurring during burial.

Interpretation of the isotope values of diagenetic calcites requires an understanding of the factors that determine the absolute values and control the variation present in both $\delta^{13} \mathrm{C}$ and $\delta^{18} \mathrm{O}$. The oxygen isotope composition of calcite is dependent upon the temperature of emplacement and the isotopic composition of the precipitating fluid. By contrast, the $\delta^{13} \mathrm{C}$ composition of calcite reflects the ambient $\delta^{13} \mathrm{C}$ of dissolved bicarbonate, whose composition can vary significantly as a result of local reactions involving the decomposition of organic matter. Whereas $\delta^{13} \mathrm{C}$ may exhibit extreme variation, $\delta^{18} \mathrm{O}$ is typically less variable during each stage of calcite formation. In effect, it is relatively easy to alter the $\delta^{13} \mathrm{C}$ of bicarbonate of a diagenetic fluid because of the low total concentration of carbon dissolved in a fluid. This contrasts with $\delta^{18} \mathrm{O}$ composition of a fluid because of the high mole fraction of oxygen present within water relative to exchangeable mineral phases (Lawrence et al., 1976; Lohmann, 1988; Banner and Hanson, 1990). Thus, if vein formation and mineralization are not a continuous process (i.e., occurring as temporally discrete events under differing temperature/fluid compositions), then each stage of calcite will be marked by a characteristic $\delta^{18} \mathrm{O}$ value and delineated by highly variable $\delta^{13} \mathrm{C}$. 


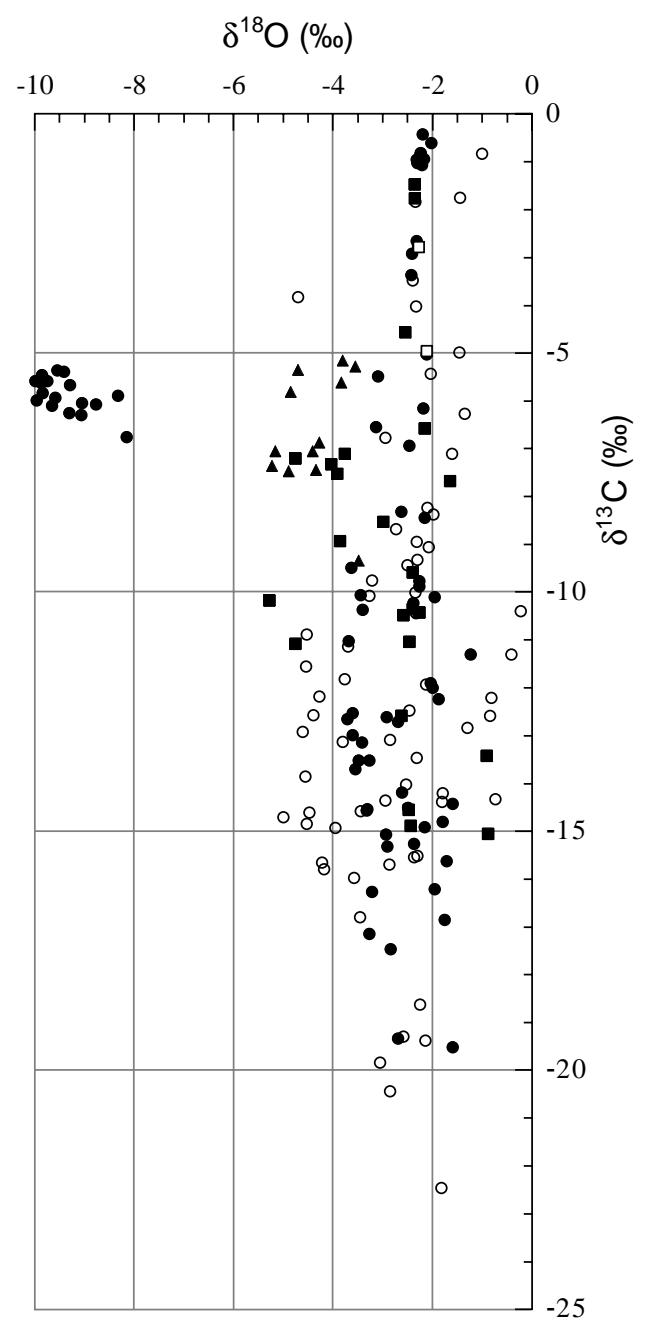

Figure 2. Carbon and oxygen isotope variation among fracture vein and intergranular cement calcites from Holes 960A and 960C. Solid triangles $=$ calcite cements from rounded lithoclasts of limestone that were cemented prior to transport to the basin. These define a narrow field between $-3.5 \%$ to $-5 \%$ o in $\delta^{18} \mathrm{O}$ and $-5 \%$ to $-7.5 \%$ in $\delta^{13} \mathrm{C}$. Solid circles = fractures in Hole $960 \mathrm{~A}$; solid squares $=$ fractures in Hole $960 \mathrm{C}$; open circles $=$ intergranular cements.

This pattern can be seen when subsets of samples are examined from individual horizons at a site (Fig. 3). In the case of vein calcites observed at Site 960, we have identified five stages of fracture and vein mineralization, enumerated Stages A-E, based upon characteristic oxygen isotope compositions. The mean compositions are as follows: Stage A, $-1 \%$; Stage B, $-2.5 \%$; Stage C, $-3.5 \%$; Stage D, $-5 \%$; and Stage E, $-9 \%$. Notably, Stages A-D exhibit broad variation in $\delta^{13} \mathrm{C}$ over the $\delta^{18} \mathrm{O}$ range of $-1 \%$ o to $-5.5 \%$ o. This suggests that Stages A-D reflect formation over a range of temperatures in diagenetic fluids whose $\delta^{13} \mathrm{C}$ composition was controlled by concomitant decomposition of organic material within the sediment. Similar patterns of variation have been documented for the organic-rich sequences of the Monterey Formation and other formations (Murata et al., 1969; Irwin et al., 1977; Friedman and Murata, 1979). Stage E, however, exhibits little $\delta^{13} \mathrm{C}$ variation.

Unfortunately, it was not possible to develop unequivocally the temporal sequence for all of the stages of fracture formation. We were, however, able to demonstrate that Stage D postdates emplacement of Stage C, based upon crosscutting relations in Sample 159960C-26R, 63-65 cm. In this case, a vein of luminescent Stage D calcite infills a fracture which bisects a Stage $\mathrm{C}$ vein. Moreover, Stage $\mathrm{E}$ fractures postdate all other fractures present within these cores and

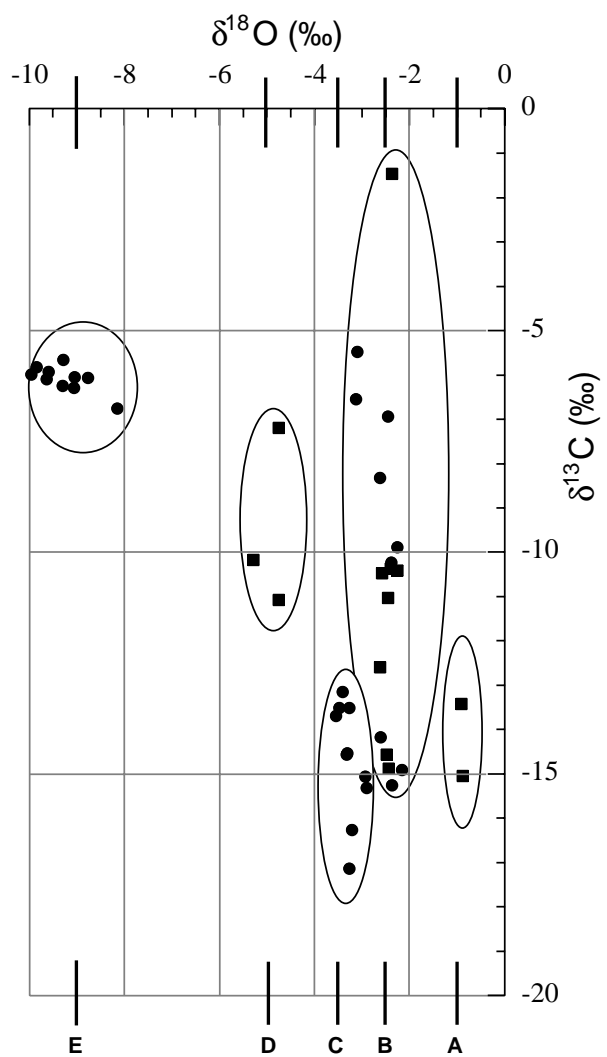

Figure 3. Carbon and oxygen isotope variation in fracture vein calcites of selected samples from Holes 960A and 960C. Within these samples, the high degree of $\delta^{13} \mathrm{C}$ variation allows identification of $\delta^{18} \mathrm{O}$ calcite values, which reflect distinct cementation events. In this case, five episodes of emplacement of calcite are observed. Although petrographic relations do not directly define the relative timing of each event, in these samples, Stage D postdates Stage C (based on crosscutting vein relationships), and Stage E postdates all other fractures. Circles $=$ Hole 960A; squares $=$ Hole 960C.

occur in sediments as young as early Eocene. This temporal relationship will be of major importance when considering the timing of the latest deformation of these sequences.

Separation of fracture mineralization based on $\delta^{18} \mathrm{O}$ values becomes more difficult when data from all samples are combined for an individual site. For example, Figure 4 shows the isotopic composition of all fracture calcites measured in Holes 960A and 960C. Although the overall trends among stages remain, overlap in composition suggests that formation of Stages A-D may record a more continuous process in an evolving system where variation in both degree of organic decomposition and temperature must have occurred. Significantly, however, Stage E remains as a distinct phase of fracturing and vein calcite emplacement.

Intergranular cements have a range of compositions similar to that of the fracture vein calcites (Fig. 2). Although it is possible in individual samples of fracture calcites to discriminate among stageswhen all analyses of intergranular cement are combined-distinct events merge into a continuum of variation. However, because the compositional range of cements is similar to that of fracture veins, this suggests that the bulk of intergranular cementation of limestone units occurred under diagenetic conditions comparable to fracture vein mineralization and were likely coincident in time. The $\delta^{18} \mathrm{O}$ values of calcites with values of $0 \%$ o to $-5 \%$ o would correspond to a temperature range of $10^{\circ}$ to $40^{\circ} \mathrm{C}$ given a $\delta^{18} \mathrm{O}$ water of $0 \%$ to $-1 \%$ o SMOW. Such temperatures are compatible with precipitation of both cements and fracture mineralization during burial in a region with a geothermal gradient of $30\left({ }^{\circ} \mathrm{C} / \mathrm{km}\right)$. 


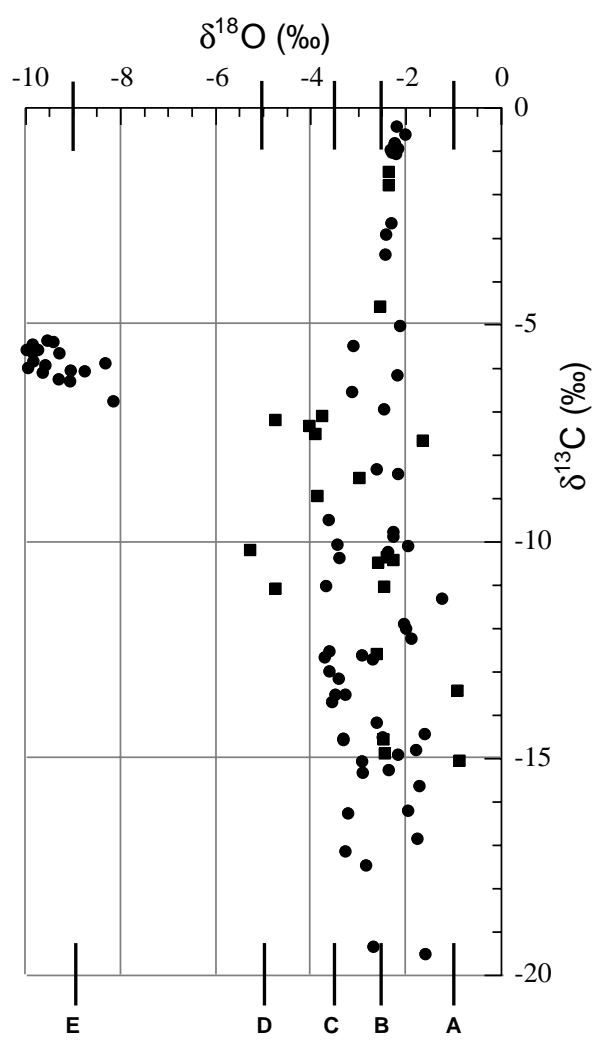

Figure 4. Carbon and oxygen isotope variation among all fracture vein calcites from Holes 960A and 960C. Although additional variation in the isotopic composition of these fracture calcites is present when all samples are included, the overall trends observed in Figure 3 can still be identified. Most notable is the distinction of Stage E, which exhibits significantly less variation in $\delta^{13} \mathrm{C}$ yet is separated from the bulk of fracture calcites based on a very negative $\delta^{18} \mathrm{O}$ composition. Circles $=960 \mathrm{~A}$; squares $=960 \mathrm{C}$.

Only in one example, has petrographic evidence of cementation and lithification prior to burial been observed. These are rounded lithoclasts of limestone recovered from Holes 960A and 960C, which were cemented prior to transport. Intergranular cements were sampled from these clasts for comparison with fracture and burial cements recovered from the limestone Unit IVA (Fig. 2, solid triangles). Isotopic analyses cluster with a mean $\delta^{18} \mathrm{O}$ value of $-4.5 \%$. At this stage, it is not possible to discriminate these from Stage D fracture cements based on their $\delta^{18} \mathrm{O}$ composition. However, the paragenetic sequence of cementation requires that these were cemented prior to deposition implying precipitation of these early cements under conditions of a negative $\delta^{18} \mathrm{O}$ water shortly after reef formation. One possible scenario to explain these isotopic compositions would be alteration of the reefal system in response to exposure to meteoric waters. Unfortunately, a meteoric origin can not be unequivocally demonstrated based solely on petrographic observations (Lohmann, 1988) given the similarity of dissolution features developed within deep marine and shallow meteoric conditions. However, if correct, alteration by meteoric waters would suggest uplift of the marginal ridge and its rimming reefal carbonates during the Turonian-Coniacian. An alternative explanation for the negative $\delta^{18} \mathrm{O}$ values for these cements would require that early formed cements were subsequently recrystallized and their isotopic compositions reset during burial diagenesis.

When isotopic data are examined relative to present depths of burial (Fig. 5), depth trends are not observed for fracture Stages A$\mathrm{D}\left(\delta^{18} \mathrm{O}-1 \%\right.$ o to $\left.-5 \%\right)$. At the greatest depth in each core (Units IVB and $\mathrm{V})$, only Stage $\mathrm{E}$ calcites are present $\left(\delta^{18} \mathrm{O}-8 \%\right.$ o to $-10 \%$ ). How-

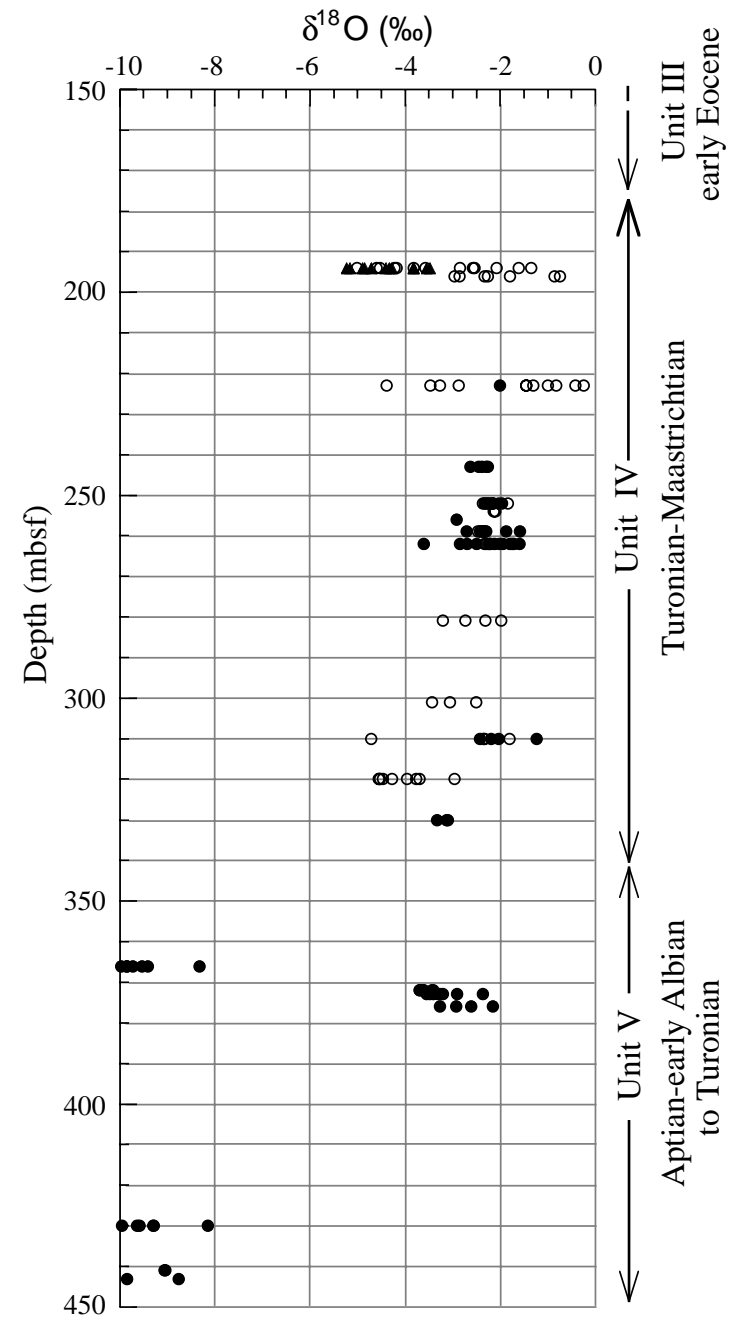

Figure 5. Distribution of oxygen isotope values with depth below seafloor for cements (open circles) and fracture vein calcites (solid circles) from Hole 960A. Solid triangles $=$ intergranular cements within lithoclasts. In this example, Stage E calcites are restricted to fractures occurring in Subunits VA and VB at Hole 960A. Stages A through D occur predominantly in Subunits IVA and VB but extend downward into Subunits VB (Core 159-960A-46R).

ever, the occurrence of Stage $\mathrm{E}$ in units above and below the unconformity (Hole 959D) separating Unit IVB from deformed sediments of Unit V requires that emplacement of Stage E calcites was not related to the Albian uplift of the margin but rather postdates deposition of the Turonian-Coniacian limestones of Unit IVB. This is compatible with other evidence that argues for Stage $\mathrm{E}$ being of a much younger age (late Paleocene to early Eocene, see below).

Fracture vein calcites recovered from Hole 959D (Fig. 6) exhibit trends similar to those observed at Site 960, although only three stages were observed. The first is characterized by $\delta^{18} \mathrm{O}$ compositions of $-2.5 \%$ o to $-4.5 \%$; the second $-4.5 \%$ o to $-7 \%$; and the third $-7 \%$ o to $-10 \%$. When compared to Site 960 , the first trend overlaps the ranges of Stages B through $\mathrm{D}$, and the second trend is offset to more negative values from Stage D. The overall character of the first two trends suggests a burial origin similar to Stages A-C observed at Site 960. The offset of $\delta^{18} \mathrm{O}$ values toward more negative values may reflect the greater depths of sediment burial at Site 959 (1060 mbsf, relative to $210 \mathrm{mbsf}$ at Hole $960 \mathrm{C}$ and $185 \mathrm{mbsf}$ at Hole 960A).

The latest stage of fracture vein calcite is similar in composition and range to Stage E observed at Site 960 with an average composition of $-9 \%$ (Fig. 6). It is important to note that at Site 959, this frac- 


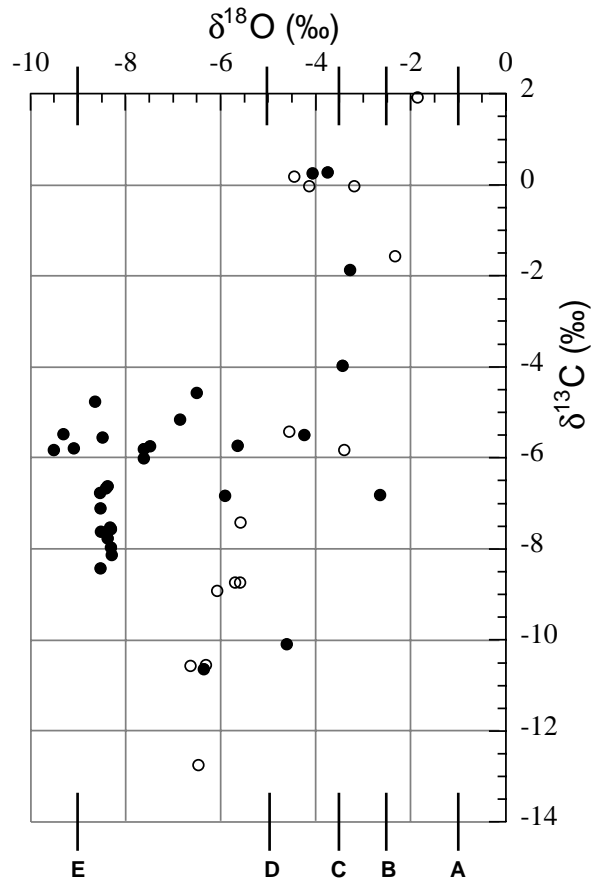

Figure 6. Carbon and oxygen isotope variation among fracture vein and intergranular cement calcites from Hole 959D. As illustrated for Site 960, fracture vein and intergranular calcite cements define distinctive $\delta^{18} \mathrm{O}$ stages based upon their combined $\delta^{13} \mathrm{C}$ and $\delta^{18} \mathrm{O}$ variation. At this site, which represents a significantly thicker section, $\delta^{18} \mathrm{O}$ values for early calcites are more negative. If such cements can be correlated between Sites 959 and 960, this would suggest cementation by Stages C and D, followed by Stage E. Stage D cements are more negative at this site than at Site 960, perhaps reflecting the overall thicker succession at Site 959. Solid circles $=$ fractures; open circles $=$ intergranular cements.

ture vein calcite, Stage E, occurs over a broad stratigraphic thickness. For example, Stage E calcite (Fig. 7), developed in massive fractures in Subunit IIC (Sample 159-959D-36R-4, 126-127 cm) has identical compositions to veins formed in Units IV and V (Samples 159-959D67R-CC, 10-16 cm; 159-959D-72R-3, 35-37 cm; and 159-959D$78 \mathrm{R}-1,138-140 \mathrm{~cm})$. On this basis, this stage of deformation and fracture vein mineralization must postdate the early to middle Eocene depositional age of Section 159-959D-36R-4.

Data from fracture vein calcite developed at Hole 962D (Fig. 8) are included for comparison with Sites 959 and 960 . At this site, fracture calcites exhibit a similar range in $\delta^{18} \mathrm{O}$ values to those observed at other sites. The majority of calcite values overlap the range of Stages B-D identified at Site 960. Calcite with the most negative $\delta^{18} \mathrm{O}$ values overlap the range of Stage $\mathrm{E}$ and occur in late Albian sediments of Unit III. Note that the $\delta^{13} \mathrm{C}$ values are uniformly more positive than values observed at Sites 959 and 960 . This likely reflects the lower sedimentation rate and lower preservation of organic carbon within the sedimentary sequence. As such, the role of organic decomposition reactions within the sediment at Site 962 plays a subordinate role to dissolution-precipitation reactions of carbonate phases.

\section{IMPLICATIONS FOR EVOLUTION OF THE CÔTE D'IVOIRE-GHANA MARGINAL RIDGE}

Deformation of the marginal ridge complex is recorded in the development of tectonic fracture veins and breccias and in the evolution of the depositional environments (Fig. 9). As discussed above, synrift/transform deformation is manifested in the development of strike-slip basins in response to movement along the transform mar-

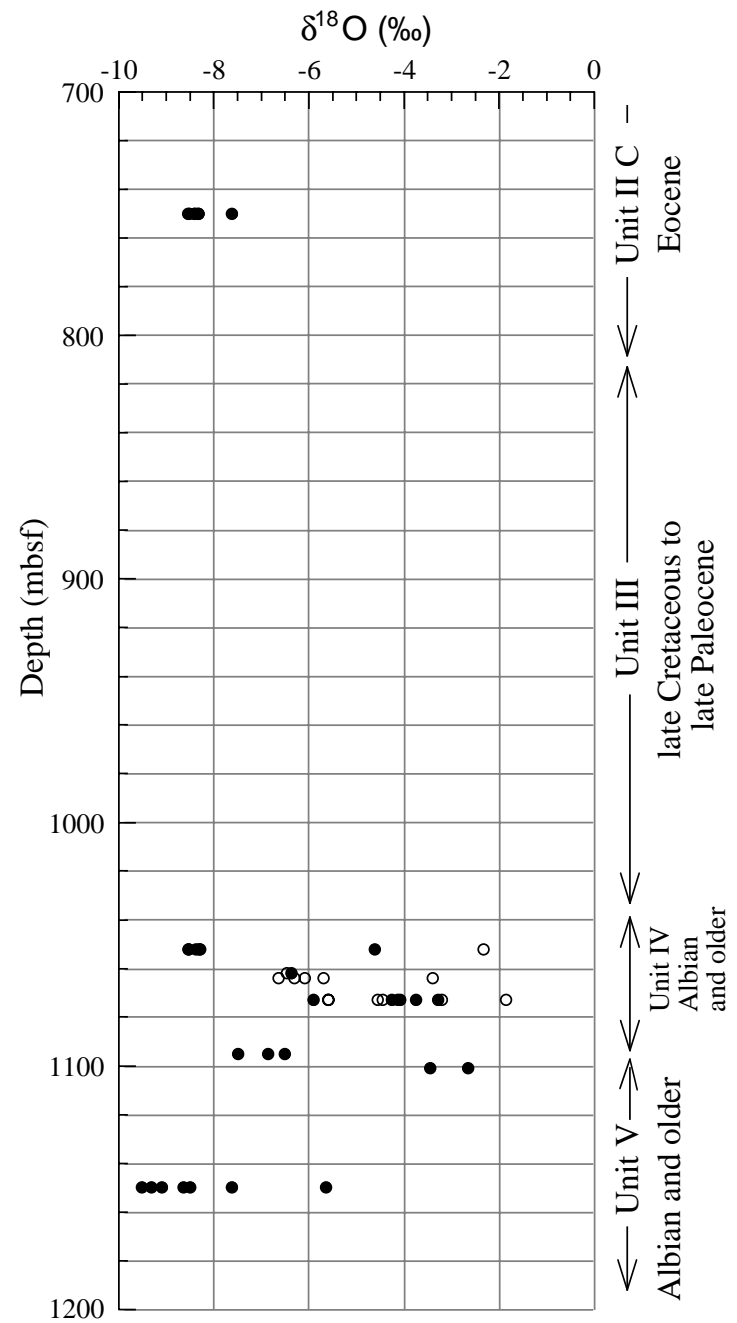

Figure 7. Distribution of oxygen isotope values with depth below seafloor for cements (open circles) and fracture vein calcites (solid circles) from Hole 959D. At this site, early stages of cementation are observed in lithologic Units IV and V. This may reflect, in part, the absence of samples from fractures in shallower units. Importantly, however, Stage E calcites are present in fractures developed in lithologic Subunit IIC (Sample 159-959D-36R-4, $126-127 \mathrm{~cm}$ ) of early to middle Eocene in age. In this sample, calcites represent the final phase of vein fill in fractures lined with chalcedony (fig. 46, Shipboard Scientific Party, 1996a).

gin between South America and Africa (Shipboard Scientific Party, 1996a). Following deposition of lacustrine to marine sediments (Fig. 9A), a major phase of deformation and structural inversion occurred in the late Albian. This deformational event led to the regional uplift of the margin and development of an erosional and angular unconformity between Units V and IV at Sites 959 and 960. This episode has been interpreted as the time of separation of South America from Africa (Fig. 9B). Following uplift, the first record of sedimentation in this region is of peri-platform reefal carbonates intercalated with pelagic foraminifer-rich sediments (Sites 959 and 960). The age of these reefal sediments is late Albian (cc-86) to Coniacian at Site 959 and early Turonian to Early Coniacian at Site 960. Based on calculations using an average spreading rate for the Mid-Atlantic Ridge, it has been suggested that development of these shallow reefal platforms coincided with the passage of the spreading ridge along the transform margin leading to a thermally driven uplift of the marginal ridge (Shipboard Scientific Party, 1996a) The colonization of the marginal ridge by shallow-water reefal communities during this time 


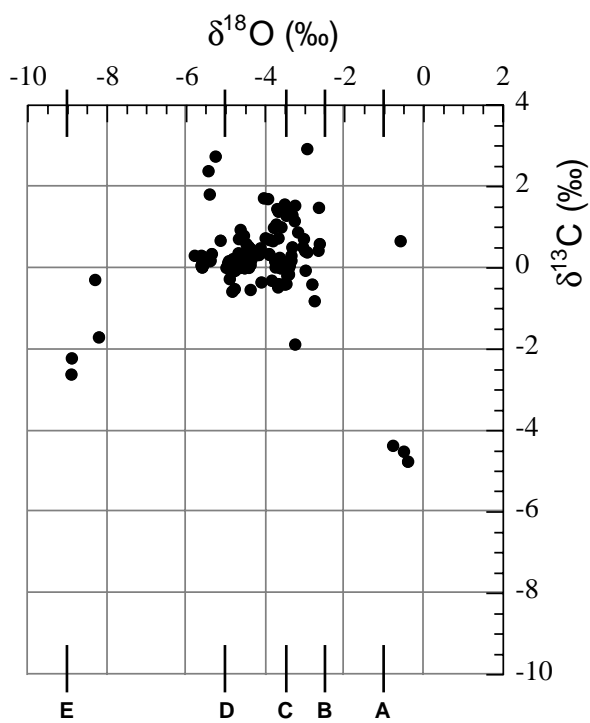

Figure 8. Carbon and oxygen isotope variation among fracture vein calcites from Site 962. Unlike fracture vein calcites from other locations, these exhibit less variation in $\delta^{13} \mathrm{C}$, which makes identification of stages of cementation more difficult. Stage A is clearly defined. Stages B, C, and D merge into a continuous field of variation, yet they define a range comparable to that observed from Sites 959 and 960 from $-3 \%$ to $-6 \%$ o $\delta^{18} \mathrm{O}$. Again, Stage E is clearly defined with an average composition of $-9 \%$ o $\delta^{18} \mathrm{O}$. Solid circles $=$ fractures.

was invoked as supporting evidence that this represented the time of maximum uplift following the detachment of South America (Shipboard Scientific Party, 1996a). Isotopic data presented here and reevaluation of the sedimentologic character of the reefal deposits suggest an alternative scenario.

It is clear that a major phase of deformation must have occurred prior to the initiation of shallow-water reefs, which are recorded in Subunit IVB at Sites 959 and 960 . This is evidenced by the deformed and fractured nature of Unit V, and the development of an angular unconformity at these sites. In contrast to previous interpretations, the presence of coarse siliciclastics comprising angular feldspar and igneous and metamorphic quartz requires that the source of the sediment must be crystalline continental crust located to the south. While the major detachment of South America might have occurred prior to this time, sedimentologic evidence requires that at least a trailing sliver of continental crust must have been retained as part of the uplifted marginal ridge (Fig. 9B) The co-association of coarse and mineralogically immature clastics and reefal carbonate could easily be accommodated by the colonization of shallow water environments rimming this continental block. Re-activation of older sedimentary deposits can not be invoked because of the immature nature of the associated siliciclastics. With continued motion along the transform margin and removal of crustal block and slivers to the south, the source of clastics would be terminal and progressive subsidence of the margin could occur. This is recorded in the development of regionally extensive hardgrounds which overlie the peri-platform carbonate deposits.

In such a scenario, what would be the timing of the passage of the spreading ridge, and what effect would this have on the sediments of the marginal ridge? It is important to note that following deposition of reefal peri-platform deposits, there is no evidence of significant shallowing of the marginal ridge present in the sedimentary record. Overall, all units following hardground development formed in waters $>200 \mathrm{~m}$ of depth (based on benthic foraminifer assemblages; R.D. Norris, Chap. 34, this volume).

If the passing of the spreading ridge did result in a thermal uplift of the margin, its effect was not as significant as the structural uplift which occurred during the detachment of South America. There is no evidence of extreme shallowing of the depositional environments over the ridge in the sedimentary record. If not recorded as a change in depositional depth, what other evidence of a thermal perturbation might be preserved? As noted above, development of tectonic fractures with vein mineralization is restricted to units of early Eocene age and older. On this basis, one might argue that the development of the tectonic veins and deformation in the Eocene might record uplift because of such a thermal event. Additional evidence supports the concept of a thermal event superimposed on the stratigraphic succession of the early Eocene and older ages. At $750 \mathrm{mbsf}$ in Hole 959D, a major discontinuity in bulk density, porosity (Shipboard Scientific Party, 1996b), and seismic velocity (Edwards, Chap. 22, this volume) is developed. Above this level, sediment porosity decreases uniformly in response to increasing burial depth. Also at $750 \mathrm{mbsf}$ the degree of thermal maturation of organic matter changes (Wagner, Chap. 41, this volume). Organic matter below 750 mbsf is thermally mature; above this depth, it is immature. Coincidence of these features, in combination with the highest occurrence of fracture vein mineralization (Stage E), argues for alteration of the sedimentary sequence below $750 \mathrm{mbsf}$ in response to a pervasive diagenetic event.

It is important to note that Stage $\mathrm{E}$, the youngest of the veining events, also records the lightest $\delta^{18} \mathrm{O}$ values. Given reasonable estimates of the isotopic composition of interstitial water, it is possible to constrain the maximum temperature represented by these fracture calcites. For example, assuming an oxygen isotopic composition of interstitial waters in equilibrium with ambient seawater during the Eocene of $0 \%$ o to $-1 \%$ o SMOW (Zachos et al., 1993), the temperature required to precipitate calcite of Stage $\mathrm{E} \delta^{18} \mathrm{O}$ values (Friedman and O'Neil, 1977) would range from $50^{\circ}$ to $70^{\circ} \mathrm{C}$ (Fig. 10), a temperature far greater than would be expected based on reasonable thermal gradients for this region $\left(30^{\circ}\right.$ to $\left.50^{\circ} \mathrm{C} / \mathrm{km}\right)$. Further constraints can be placed on maximum temperatures by considering a range in the composition of interstitial waters. The only mechanism for significantly altering pore-water compositions is through low- or high-temperature interaction with seafloor basalt (Shanks et al., 1995; Lawrence et al., 1976). For example, pore water with significantly more negative $\delta^{18} \mathrm{O}$ values (e.g., $-5 \%$ ), could be obtained through low-temperature alteration of basalts to zeolites. Alternatively, more positive values (e.g., $+2 \%$ o) could occur in response to high temperature alteration and exchange with basalt. In all of these examples, the maximum temperature obtainable for the emplacement of Stage E calcite would be approximately $85^{\circ} \mathrm{C}$ (Fig. 10). Clearly, within this succession, Stage E $\delta^{18} \mathrm{O}$ values represent the highest temperature recorded in fracture vein calcites.

Given the tectonic setting of the Côte D'Ivoire-Ghana Marginal Ridge and the limited options for elevating the geothermal gradient of this region during the late Paleogene, the most likely mechanism is the passage of the spreading ridge along the southern edge of the Côte D'Ivoire-Ghana Marginal Ridge during early to middle Eocene times. Such a thermal event could elevate pore-water temperatures and lead to convectively driven upward flow of these waters through the network of tectonic fractures. This, in turn, could account for the abrupt changes that are observed in thermal maturity of organic material and the discontinuity in seismic and sediment physical properties of early Eocene and older strata. The magnitude of this thermal event, however, must not have been high enough to initiate the thermally driven uplift of the margin because of the lack of discernible shallowing of the depositional facies at this time.

\section{CONCLUSIONS}

A record of the evolution of pore-water temperatures and compositions is preserved within vein and pore-filling cements present within the stratigraphic succession retrieved from the Côte d'Ivoire Transform Margin. Specifically, calcite precipitated in tectonic fracture veins and as intergranular cements provide a chemical record of 


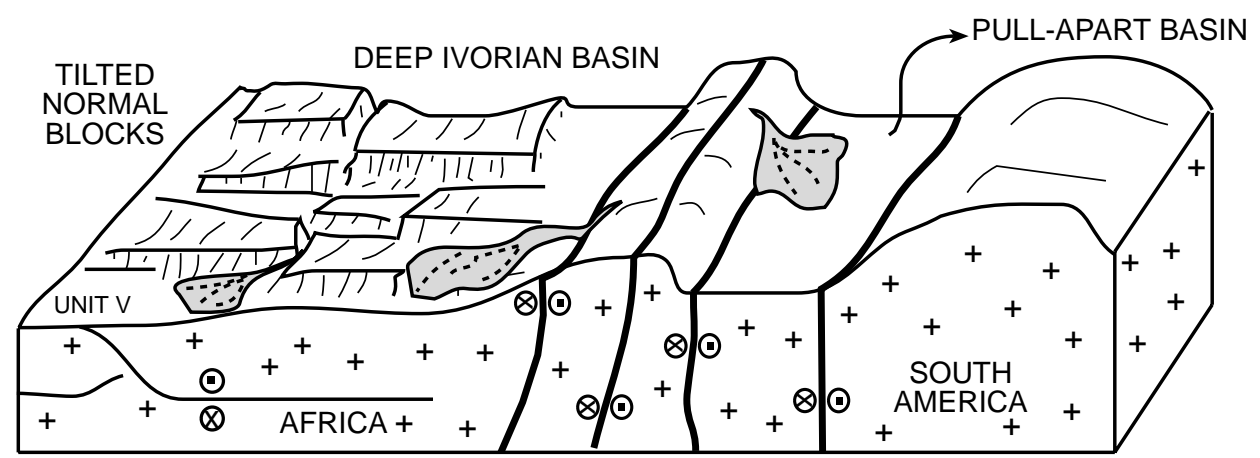

\section{A. Late Albian}
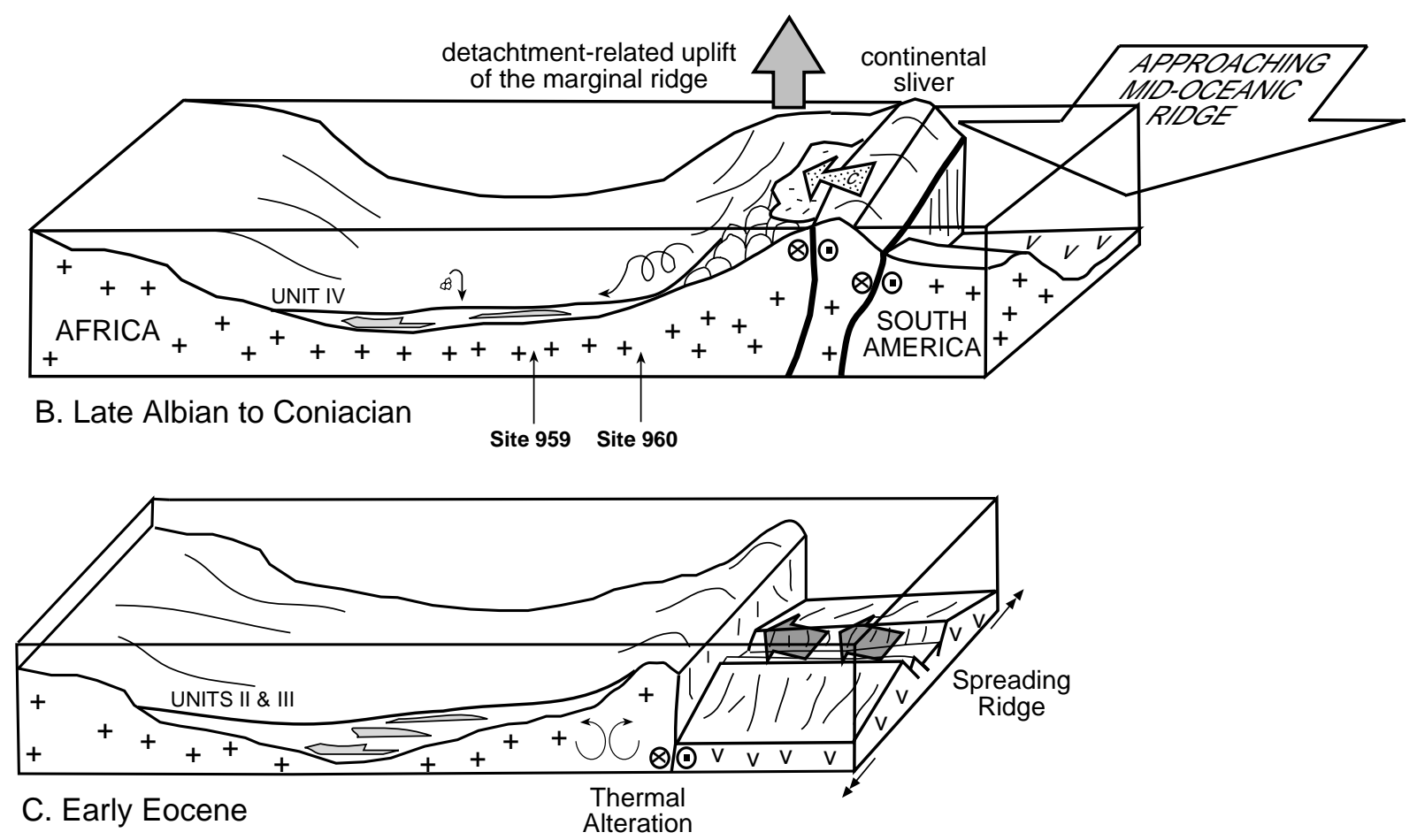

Figure 9. Schematic illustration of the evolution of the transform margin between the African and South American continents from Late Cretaceous through early Eocene times (modified from Shipboard Scientific Party, 1996a). A. Syntransform, intracontinental basin stage. Sedimentation during the late Albian was dominated by continental and lacustrine environments in pull apart basins developed by transcurrent shear between the South American and African continental blocks. Continental deposits grade upward into transitional marine sediments with the encroachment of marine conditions in the region of the marginal ridge as continental separation proceeds. Circled $\mathrm{x}=$ inward relative motion; circled dots $=$ outward relative motion. B. Marginal ridge emergence and initiation of subsidence in the Deep Ivorian Basin (late Albian to Coniacian). Emergence of the marginal ridge is marked by development of an erosional and angular unconformity above Unit V at Sites 959 and 960. Above this unconformity, intercalation of limestone and coarse siliciclastic peri-platform deposits with foraminifer-rich pelagic limestones indicates the establishment of shallow-water carbonate reefal environments on an emergent block to the south. The presence of angular metamorphic and igneous quartz and abundant plagioclase in these siliciclastic deposits suggests incomplete separation of South America from Africa, or the presence of a sliver of continental crust, during this time. The oceanic spreading ridge resides to the east of the transform margin at this time. C. Submergence of the marginal ridge and formation of the Deep Ivorian Basin (late Coniacian to early Eocene) followed by passage of the oceanic spreading ridge. Thermal alteration of the sediments comprising the marginal ridge is indicated by a discontinuity in the thermal maturation and physical and seismic properties of early Eocene and older sediments compared to overlying middle Eocene to Holocene sediments.

the sequential changes which have affected the lithification of carbonate-rich sediments during episodes of uplift and burial. This project has examined these phases within the context of the tectonic and sedimentologic framework to provide insight into the uplift and subsidence history of the marginal ridge, and the relationship between tectonic fracture generation and thermal perturbations associated with the tectonic separation of the African and South American continents during Late Cretaceous to Eocene times.

\section{ACKNOWLEDGMENTS}

Many thanks go to the Shipboard Party, whose great insights and energies provided an exciting forum within which this research could be undertaken. Funding of research was provided by USSAC-NSF (KCL) and the University of Edinburgh (EAP) and NSERC (EAP). This research would not have been completed without the continuing efforts of Ms. Lora Wingate, whose technical skill ensured the high- 


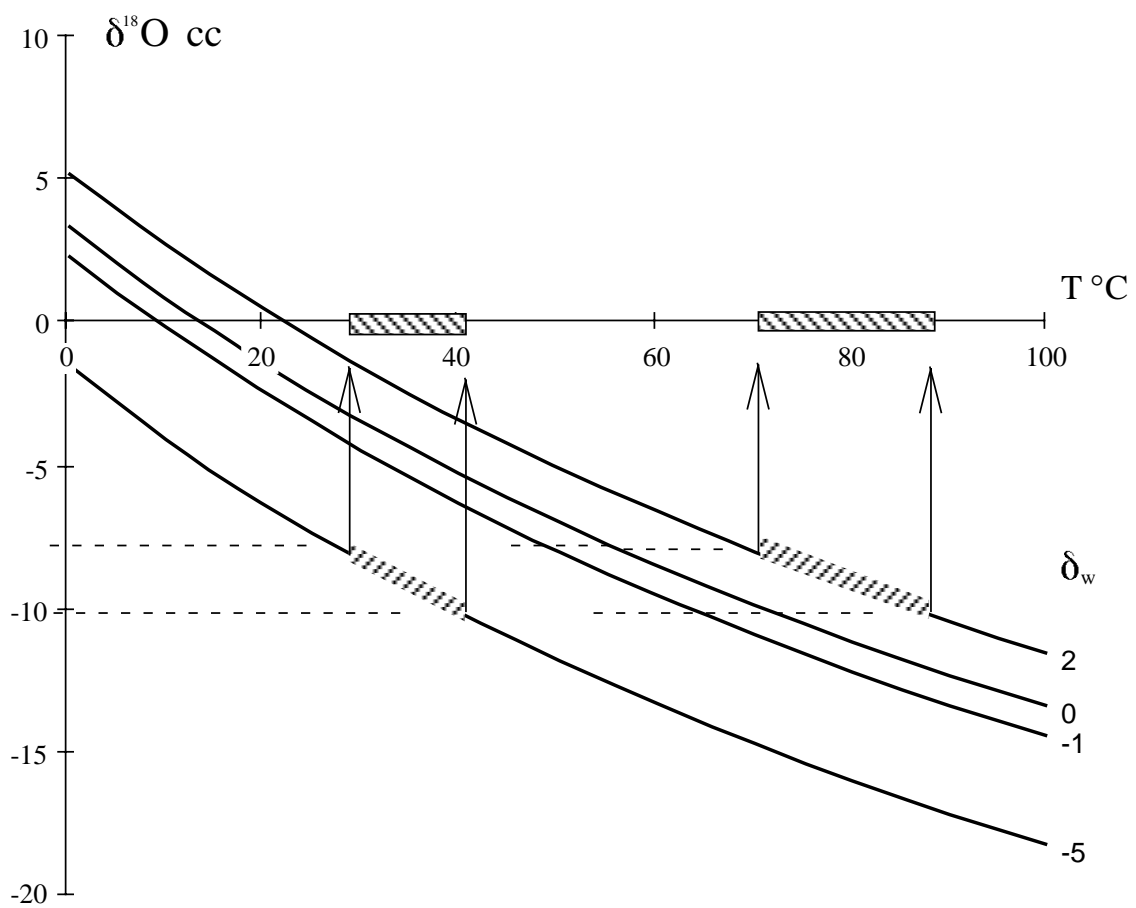

Figure 10. Range of temperatures and water compositions possible for precipitation of Stage E calcites. Given the range of observed $\delta^{18} \mathrm{O}$ values for fracture vein calcites observed through the region of the Côte D'Ivoire-Ghana Marginal Ridge, it is possible to constrain the maximum temperatures of emplacement of these calcites given a reasonable range of water compositions (dw). In this example, $\delta^{18} \mathrm{O}$ water is varied between +2 and -5 . Under conditions where diagenetic waters are derived from hydrothermal alteration of basalt at high temperatures at low water/rock ratios, the isotopic composition of this fluid would converge to a value of $+1 \%$ o to $+2 \%$ SMOW. Given the range of fracture vein calcite $\delta^{18} \mathrm{O}$ values of $-8 \%$ to $-10 \%$, $85^{\circ} \mathrm{C}$ represents the highest temperature observed for the early Eocene and older sequence. est quality of data from the University of Michigan Stable Isotope Laboratory.

\section{REFERENCES}

Banner, J.L., and Hanson, G.N., 1990. Calculation of simultaneous isotopic and trace element variations during water-rock interaction with applications to carbonate diagenesis. Geochim. Cosmochim. Acta, 54:31233137.

Basile, C., 1990. Analyse structurale et modélisation analogique d'une marge transformante: l'exemple de la marge profonde de Côte d'Ivoire-Ghana. Mem. Doc. CAESS Rennes, 39.

Basile, C., Brun, J.P., and Mascle, J., 1992. Structure et formation de la marge transformante de Côte d'Ivoire-Ghana: apports de la sismique réflexion et de la modélisation analogique. Bull. Soc. Geol. Fr., 163:207216.

Basile, C., Mascle, J., Popoff, M., Bouillin, J.P., and Mascle, G., 1993. The Côte d'Ivoire-Ghana transform margin: a marginal ridge structure deduced from seismic data. Tectonophysics, 222:1-19.

Freeman-Lynde, R.P., Fulker-Whitley, K., and Lohmann, K.C., 1986. Origin of cements in Bahamian escarpment limestones. J. Sediment. Petrol., 56:799-811.

Friedman, I., and Murata, K., 1979. Origin of dolomite in Miocene Monterey Shale and related formation of the Temblor Range, California. diagenesis. Geochim. Cosmochim. Acta, 43:1357-1365.

Freidman, I., and O'Neil, J.R., 1977. Compilation of stable isotope fractionation factors of geochemical interest. Geol. Surv. Prof. Pap. U.S., 440$\mathrm{K}: 12$.

Graber, E., and Lohmann, K.C., 1988. Basinal marine dolomicrite from the Pennsylvanian/Wolfcampian Horquilla Formation, New Mexico. J. Sediment. Petrol., 59:4-12.

Irwin, H., Curtis, C., and Coleman, M., 1977. Isotopic evidence for source of diagenetic carbonates formed during burial of organic-rich sediments. Nature, 269:209-213.

James, N.P., and Choquette, P.W., 1990. Limestones-the sea-floor diagenetic environment. In McIlreath, I.A., and Morrow, D.W. (Eds.), Diagenesis. Geosci. Can., 4:13-34.

Lawrence, J.R., Gieskes, J., and Anderson, T.F., 1976. Oxygen isotope material balance calculations, Leg 35. In Hollister, C.D., Craddock, C., et al., Init. Repts. DSDP, 35: Washington (U.S. Govt. Printing Office), 507-512.

Lohmann, K.C., 1988. Geochemical patterns of meteoric diagenetic systems and their application to studies of paleokarst. In James, N.P., and Choquette, P.W. (Eds.), Paleokarst: New York (Springer-Verlag), 58-80.
Mascle, J., Basile, C., Pontoise, B., and Sage, F., 1995. The Côte d'IvoireGhana transform margin: an example of an ocean-continent transform boundary. In Banda, E., Talwani, M., and Thorne, M. (Eds.), Rifted Ocean-Continent Boundaries, NATO ASI Ser.: Dordrecht (Kluwer), 327-339.

Mascle, J., and Equanaute Scientific Party, 1994. Les marges continentales transformantes Ouest-Africaines-Côte d'Ivoire, Ghana, Guinée. IFREMER, Ser. Rep. Ocean, 5:1-119.

Mascle, J., Guiraud, M., Basile, C., Benkhelil, J., Bouillin, J.P., Cousin, M., and Mascle, G., 1993. La marge transformante de Côte d'Ivoire-Ghana: premiers résultats de la campagne Equanaute (Juin 1992) [The Côte d'Ivoire-Ghana transform margin: preliminary results from the Equanaute cruise (June 1992)]. C. R. Acad. Sci. Ser. 2, 316:1255-1261.

Mascle, J., Lohmann, G.P., Clift, P.D., et al., 1996. Proc. ODP, Init. Repts., 159: College Station, TX (Ocean Drilling Program).

Murata, K.J., Friedman, I., and Madsen, B.M., 1969. Isotopic composition of diagenetic carbonates in marine Miocene formation of California and Oregon. U.S. Geol. Surv. Prof. Pap., 614-B.

Shanks, W.C., III., Böhlke, J.K., Seal, R.R., II, 1995. Stable isotopes in midocean ridge hydrothermal systems: interactions between fluids, minerals, and organisms. In Humphris, S.E., Zierenberg, R.A., Mullineaux, L.S., Thompson, R.E. (Eds.), Seafloor Hydrothermal Systems: Physical, Chemical, Biological, and Geological Interactions. Geophys. Monogr., 91:194-221.

Shipboard Scientific Party, 1996a. Principal results. In Mascle, J., Lohmann, G.P., Clift, P.D., et al., Proc. ODP, Init. Repts., 159: College Station, TX (Ocean Drilling Program), 297-314.

, 1996b. Site 959. In Mascle, J., Lohmann, G.P., Clift, P.D., et al., Proc. ODP, Init. Repts., 159: College Station, TX (Ocean Drilling Program), 65-150.

1996c. Site 960. In Mascle, J., Lohmann, G.P., Clift, P.D., et al., Proc. ODP, Init. Repts., 159: College Station, TX (Ocean Drilling Program), 151-215.

Zachos, J.C., Lohmann, K.C., Walker, J.C.G., and Wise, S.W., Jr., 1993. Abrupt climate change and transient climates during the Paleogene: a marine perspective. J. Geol., 101:191-213.

Date of initial receipt: 18 September 1996

Date of acceptance: 9 June 1997

Ms 159SR-010 